\title{
READING AND CRITICAL THINKING SKILLS OF UNDERGRADUATE STUDENTS: A QUANTITATIVE ANALYSIS
}

\author{
Jana Javorčíková ${ }^{1}$, Mária Badinská \\ ${ }^{1}$ Faculty of Arts, Matej Bel University, Banská Bystrica, Slovakia \\ ${ }^{2}$ Faculty of Political Science and International Relations, MBU, Banská Bystrica, Slovakia
}

\begin{abstract}
This paper will show the results of quantitative analysis conducted in September 2020, based on a 113-respondent sample unit of adult readers in English (100 Slovak and 13 international respondents). Researchers analysed respondents' abilities to evaluate a text critically; i.e. to identify its assumed author, genre, organization of the text, and the importance of the text for the reader and his or her community. Research outcomes proved that university undergraduates in Slovakia do not possess a good command of critical reading skills for academic reading in four out of five items. International students outscored Slovak students in two items; the research proves the need to intensify preparation of undergraduates in critical thinking in order to fit the needs of a changing society and reading load.
\end{abstract}

Key words: critical thinking, reading comprehension, reading performance, motivation, micro-skills, macro-skills

\section{INTRODUCTION}

Since the advent of the Internet in the 1990s, the intensified focus on reading has placed new demands on the quality of reading and the level of reflection on the information gathered. However, until the last three decades, literacy, reading comprehension and critical thinking were treated as nearly independent disciplines, examined by different branches of science. Reading comprehension was the subject of linguistic methodology, general literacy was analysed by educational and even political research, and critical thinking had, since the ancient Greek philosophers, been reserved for political science and philosophy, along with its subdisciplines, e.g. logic. Over the past thirty years, however, the nature and amount of reading done by amateur as well as professional readers ${ }^{1}$ (including translators, interpreters, book reviewers, educators and students) has changed dramatically. Intensification of reading and the abundance of texts requires a new complex of sub-skills for effective reading comprehension and, more importantly, critical thinking, which contributes to an individual's wellbeing. In everyday life, these abilities help readers to understand and evaluate private and public texts, distinguish fake news,

Submitted July $13^{\text {th }}, 2021$, accepted for publication August $15^{\text {th }}, 2021$

Corresponding author: Mária Badinská. Faculty of Political Science and International Relations, MBU, Banská Bystrica, Slovakia. E-mail: jana.javorcikova@umb.sk

${ }^{1}$ The term "professional reader" was analysed in the study Motivation to Read: Facts and Myths (2018). 
and make informed political and purchasing decisions, not to mention the feeling of intellectual independence they inspire (Browne and Keeley, 1981, Štefániková, 2019, 89). In professional and academic life, advanced reading and critical thinking skills enable readers (both students and instructors) to find quality sources of information and arrange them in a hierarchy, identify plagiarism and corroborate authors' authority, among other things. Taking as a starting point the direct correlation between effective reading and critical thinking (Browne and Keeley, 1981, 8), the objective of this study was a quantitative analysis of reading and critical thinking skills of Slovak undergraduate students and possible methods for their improvement. Specifically, the aim of the presented research was to determine whether Slovak university undergraduate students have a good command of critical thinking skills when reading a new academic text. The research verified hypothesis $\mathrm{H}_{0}$ in four out of five tested items (D1, D2, D3 and D5):

$\mathrm{H}_{0}: 81.56 \%{ }^{2}$ of first-year undergraduates do not have the necessary critical thinking skills for academic reading.

The alternative hypothesis was proved in only one item (D4):

$\mathrm{H}_{1}: 81.56 \%$ of first-year undergraduates have the necessary critical thinking skills for academic reading.

Compared to the national and international sample unit, international respondents exceeded the correct answer ratio in two items (D1, D3).

\section{LITERATURE REVIEW}

According to the analytical-synthetic definition popular in the past, reading was understood as a process of decoding letters, sounds, utterances, blocks of text and finally entire texts, which was thought to lead the reader to a semantic understanding of the texts (Zápotočná 2001, 1). Many scholars have recently challenged this definition and pointed out the importance of integration of the social-psychological definition of reading, which understands reading as a complex, hierarchical, multi-layered, multicomponent and dynamically changing set of psychological processes (Zápotočná, 2001, 1). The most recent studies (Cameron 2001; Grabe and Stoller 2011; Lojová and Straková 2012 and Šipošová 2017) understand reading as a fusion of analytical-synthetic and socialpsychological definitions, a complex process that goes beyond the mere recognition of words and sentences and employs a set of cognitive and linguistic processes at several levels - from the lowest level (recognizing letters, combining them into words, decoding the meaning of words, understanding how they form relationships in sentences and larger units) to the highest level - understanding the meaning of the broader whole - text and context. Research done since the 1980s has further revised behaviourist definitions of reading and integrated psychological aspects of the process and the personality of the reader. Oxford (1990) and Veverková (2020) explore cognitive (text-related) and metacognitive (reader-related) reading strategies.

The latest understanding of reading also integrates its social aspects. Scholes (1991), Alderson (2005) and Gavora (2012) emphasize the complex social nature of reading and its connection to the life of the reader. Effective reading is not limited to a specific act of reading a text; reading can only truly be considered effective when the text's content is

\footnotetext{
${ }^{2}$ The number indicates the course retention percentage and is further explained in sub-chapter 3.2.
} 
absorbed by the reader and transformed into his or her actions and thoughts. Integration of previous knowledge, skills and experience is also of key importance, especially in EFL reading, when readers often use skills acquired in their mother tongue (Straková and Cimermanová 2005, 21). Alderson calls this phenomenon a "language threshold" (Alderson, 2005) and expands the above-mentioned definitions of reading even further, stating that reading also implies understanding the broad meaning of the text, the explicit and implicit intentions of the writer, identification of the assumed writer (if not stated), and also determining the text's significance to the individual and his or her community. A structure of the complex process of reading and reading comprehension is illustrated in Fig. 1:

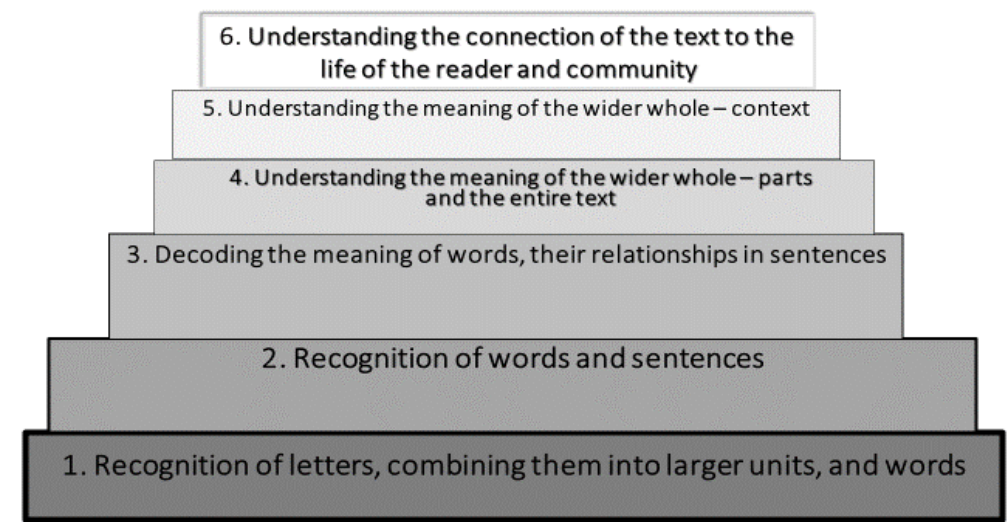

Fig. 1 Phases of reading and reading comprehension as a number of processes; Source: J. Javorčíková.

To sum up, Scholes, Gavora, and Alderson's understanding of effective reading as a fusion of physiological and mental processes that go beyond the text and relate to the reader's life and community inevitably involves methods of critical thinking.

Critical thinking is now a popular catchphrase, as well as a term examined by many disciplines. Popular sources generally define critical thinking as the ability to engage in reflective and independent thinking [which requires the readers] to use [their] ability to reason. The reader, thus, should be an active learner, not just a passive recipient of information. Critical thinkers rigorously question ideas and assumptions rather than accepting them at face value; [they] do not merely accumulate facts and knowledge or something that one can learn once and then use in that form forever. They will always seek to determine whether the ideas, arguments and findings represent the entire picture and are open to finding that they do not. In order to think critically, readers need a complex of skills, including observation, analysis, interpretation, reflection, evaluation, inference, explanation, problem solving, and decision making (Skills You Need, 2019).

World-leading researchers in the field of critical thinking further expanded the thought: "...critical thinking is reasonable and reflective thinking focused on deciding what to believe or do" (Ennis 2011, 1). Cottrell holds that "...critical thinking is really a process that begins the moment [...] students start writing and reading, the moment they start making choices and decisions about the meaning they attach to what they read and the meanings they try to employ when they are writing" (Cottrell 2005, 77). Paul understands critical thinking as a lifestyle: “...critical thinking is the art of thinking about 
thinking in an intellectually disciplined manner... [Critical thinkers] analyse thinking, they assess thinking, and they improve thinking" (Paul 2005, emphasis in original). Paul in his theory of critical thinking highlights two components: the elements of reasoning and intellectual standards. Students, in order to become strong thinkers who can grasp and navigate the challenges of university education and prepare for their future career and civic life, must understand eight elements of thought: (1) purpose, (2) key questions, (3) information, (4) concepts, assumptions, (5) implications and consequence, (6) point of view, (7) interpretation and (8) conclusion (Elder and Paul 1996).

The Paulian framework of critical thinking further encompasses intellectual standards which serve as guidelines when critical thinkers assess their own thinking; these standards are of the greatest importance for both teachers and students. They include thirty-five aspects or instructional strategies (affective strategies from S-1 to S-9, cognitive strategiesmacroabilities from S-10 to S-26, and cognitive strategies - micro-skills from S-27 to S-35), including the following: thinking independently (S-1), developing insights into egocentricity or sociocentricity (S-2), developing confidence in reason (S-9), clarifying and analysing the meaning of words or phrases (S-14), reading critically: clarifying or critiquing texts (S-21), listening critically: the art of silent dialogue (S-22), making interdisciplinary connections (S23), practicing Socratic discussion: clarifying and questioning beliefs, theories, or perspectives (S-24), thinking precisely about thinking: using critical thinking vocabulary (S28) and terms such as assume, infer, conclude, criterion, point of view, relevance, issue, elaborate, ambiguous, objection, bias, contradiction, distinguish, etc. (Elder and Paul 1977; Paul 1995, 2013; Paul and Elder, 2006).

The strategies are divided into affective strategies, macro-abilities and micro-skills as elementary skills of critical thinking; they are intertwined in order to highlight "individual moves as part of one integrated activity: the attempt to make sense of, to follow what we are reading" (Paul and Binker 1995, 5). When reading, students may start with elementary skills, for example with the implication (S35) of the book and the evaluation of assumptions (S30), shifting forward to reading precisely using critical thinking vocabulary (S28), through the macro abilities of clarifying and analysing the meaning of words and phrases (S14), issues, conclusions, or beliefs (S13), comparing analogous situations: transferring insights into new contexts (S11) in order to develop confidence in reason (S9) and intellectual good faith or integrity (S7) until they reach the point of independent thinking (S1), the highest skill of critical thinking (Paul and Binker 1995).

Incorporating these standards into the educational process requires what scholars call "metacognition" (Piršl, Popovska and Stojković 2017; Hanesová, 2014), i.e. readers'/ thinkers' focus on the immediate activity comprising the aforementioned strategies: "...consciousness is the first step; you cannot effectively determine what you need to know until you understand and try to critically evaluate, together with your teacher and peers, what you do know and what is expected of you as a student to know" (Piršl, Popovska and Stojković 2017, 603).

To sum up, modern theories of reading comprehension and writing naturally encompass methods and techniques of critical thinking. A modern effective reader is not a mere "consumer" of the text; rather, he or she is a "co-creator" of its connotative and denotative meaning(s), as well as ethical, cultural, social, political and many other implications. He or she is also a "decision-maker" and "authority", determining its significance for the life of the reader and their community. 


\section{MATERIAL AND METHODS}

\subsection{Sample Unit Description}

After adjusting the pilot-testing research tool ${ }^{3}$, a quantitative study was conducted via a controlled experiment in September 2020. 179 reading tests were administered to first-year students (159 Slovak and 20 international students), studying English teaching and translation studies at Matej Bel University, Slovakia. 66 tests were discarded (on the basis of incomplete information, respondents with reading or uncorrected vision impairment, etc.). After this, the selected sample unit consisted of 113 valid tests (100 Slovak and 13 international respondents). Quota sampling was applied for Slovak students, voluntary sampling for international students (due to the low number of international respondents).

No Slovak or international respondent had participated in speed-reading courses and none had read the text before. All respondents had passed the minimum B1 English Maturita exam ${ }^{4}$ or an acceptable alternative. Table 1 shows Slovak and international sample unit descriptors:

Table 1. Slovak and international sample unit description

\begin{tabular}{|l|c|c|c|}
\hline Descriptors: programme, CEFR & $\begin{array}{c}\text { No. of } \\
\text { Slovak } \\
\text { respondents }\end{array}$ & $\begin{array}{c}\text { No. of } \\
\text { international } \\
\text { respondents }\end{array}$ & $\begin{array}{c}\text { Total no. of } \\
\text { respondents } \\
\text { (Slovak \& international) }\end{array}$ \\
\hline Sample unit no. & 100 & 13 & 113 \\
Teaching studies students & 50 & 6 & 56 \\
Translation studies students & 50 & 7 & 57 \\
CEFR level of English achieved: & 64 & 7 & 71 \\
B2 (optimal level) & 20 & 2 & 22 \\
B1 & 15 & 2 & 17 \\
C1 & 0 & 1 & 1 \\
C2 & 1 & 1 & 2 \\
Other (Maturity exam & & & \\
in other language -Spanish) & & & \\
\hline
\end{tabular}

Source: J. Javorčíková

The average age of the Slovak sample unit was 19.96 years, the average time of studying English was 11.71 years. The average age of the international sample unit was 20.15 years, the average time of studying English was 12.62 years. The mother tongues of the international respondents were Russian, Ukrainian, Belarusian and Italian. One student was bilingual (Slovak and Italian). As a result of the internationalisation of Slovak university education, these international students were regular full-time students; therefore, they were included in the sample corpus; they were analysed separately, as well as a part of the entire research corpus.

\footnotetext{
${ }^{3}$ The pilot-testing was conducted at Matej Bel University, Department of English and American Studies in December 2019; 20 respondents.

${ }^{4}$ The Maturita is a standardized form of assessment at high schools in Slovakia, usually held in the $4^{\text {th }}$ year of high school studies. Maturita tests four integrated skills including reading and reading comprehension. A minimum CEFR level required is B1.
} 


\subsection{Research Tools (Text and Comprehension Questions), Methodology and Procedure}

An extract from a quasi-academic English text entitled Children, Teenagers, and E-books: Young People and the New Technology was used to determine the respondents' ability to read and comprehend a text and evaluate it critically. The text was adopted from the TEFL coursebook English File, Upper-intermediate (Oxenden, Latham-Koenig and Seligson 2001; CEFR B2 level); however, the researchers adapted minor details for research purposes. The text was accompanied by 15 questions; 10 questions were focused on identification of reading skills, 5 questions were critical thinking identifiers (these 5 questions will be the subject of this study). Table 2 displays the descriptive parameters of the text:

Table 2. Descriptive parameters of the text

\begin{tabular}{|l|c|c|c|c|c|c|c|}
\hline $\begin{array}{l}\text { Genre/ } \\
\text { style }\end{array}$ & $\begin{array}{c}\text { CEFR } \\
\text { level }\end{array}$ & $\begin{array}{c}\text { No. of } \\
\text { words }\end{array}$ & $\begin{array}{c}\text { No. of } \\
\text { para- } \\
\text { graphs }\end{array}$ & $\begin{array}{c}\text { No. of } \\
\text { lines }\end{array}$ & $\begin{array}{c}\text { Sentence } \\
\text { structure: } \\
\text { no. of } \\
\text { statements }\end{array}$ & $\begin{array}{c}\text { Sentence } \\
\text { structure: no. } \\
\text { of } \\
\text { interrogatives }\end{array}$ & $\begin{array}{c}\text { Specialized } \\
\text { vocabulary } \\
\text { B26 }\end{array}$ \\
\hline $\begin{array}{l}\text { Article/ } \\
\text { Academic }\end{array}$ & B2 & 509 & 5 & 33 & 25 & 1 & $\begin{array}{c}\text { e-books, } \\
\text { smartphones, } \\
\text { computer }\end{array}$ \\
\hline
\end{tabular}

Source: J. Javorčíková and S. Kováč.

The researchers analysed various texts typically used at the respondents' affiliated university (e.g. seminar readings, coursebooks, web pages, etc.) and determined the selected text to be representative of English texts used during the first year of university studies. ${ }^{7}$ In terms of size and tasks, the selected text was similar to the Maturita and PISA reading tests; which the respondents were generally aware of. The researchers decided against the use of authentic texts, as some of the field-related terminology (e.g. morpheme, derivation, etc.) categorized them as $\mathrm{C} 1$ - a level that the respondents were to achieve during their master's studies. The topic of the text (reading and book-purchasing habits of various age groups and their preferred media) was chosen because it was common to all the students of humanities (both future teachers and translators/interpreters); however, it was not a specific study focus of any respondent, and thus none had the advantage of possessing a significantly greater mastery of the topic. In terms of research methodology, based on recent research, including the PISA 2018 results, we formulated two research questions:

1. Do Slovak first-year undergraduates have a good command of critical thinking skills for academic reading?

2. What is the definition of a "good command" of critical thinking skills for academic reading for university undergraduates?

Prior to the research, it was essential to define a "good command of critical thinking skills for academic reading", a question many scholars find unanswerable (Alderson, 2005). One way of defining this phenomenon is the Gaussian curve and the method of normal distribution

\footnotetext{
${ }^{5}$ Data generated by the Microsoft Word programme.

${ }^{6}$ Checked by Text-inspector programme.

${ }^{7}$ The text was confirmed by the Text-inspector programme to be $\mathrm{B} 2$ level.
} 
of reading results. However, given the small sample unit of international respondents, we decided to use the Introduction to Linguistics and Literature course ${ }^{8}$ retention ratio, which in 2020 was 149:179 (179 students enrolled in the course; 149 students $(81.56 \%)$ passed; the course retention percentage is $81.56 \%$ ). Thus our research assumption was: $81.56 \%$ of the entire sample unit (i.e. students who will continue in their studies) should have a command of the critical reading skills necessary for academic reading. On the basis of the research questions, the following hypotheses were formulated:

$\mathrm{H}_{0}: 81.56 \%$ of first-year undergraduates do not have the necessary critical thinking skills for academic reading.

$\mathrm{H}_{1}: 81.56 \%$ of first-year undergraduates have the necessary critical thinking skills for academic reading.

\section{TOTAL RESEARCH RESULTS}

Table 3 shows the research results separately for Slovak and international students as well as cumulative results for the entire research sample unit:

Table 3 Total research results - Slovak vs. international respondents

\begin{tabular}{|l|c|c|c|c|c|c|c|}
\hline $\begin{array}{l}\text { Descriptors } \\
\text { (D) 1-5 }\end{array}$ & $\begin{array}{c}\text { No. of } \\
\text { Slovak } \\
\text { Res- } \\
\text { pondents - } \\
\text { correct } \\
\text { answers } \\
\text { (max. 100) }\end{array}$ & $\begin{array}{c}\text { Slovak } \\
\text { Res- } \\
\text { pondents } \\
(\%)\end{array}$ & $\begin{array}{c}\text { No. of } \\
\text { Internat. } \\
\text { Res- } \\
\text { pondents- } \\
\text { correct } \\
\text { answers } \\
\text { (max. 13) }\end{array}$ & $\begin{array}{c}\text { Intern. } \\
\text { Res- } \\
\text { pon- } \\
\text { dents } \\
(\%)\end{array}$ & $\begin{array}{c}\text { Entire } \\
\text { corpus- } \\
\text { Total no. } \\
\text { of correct } \\
\text { answers } \\
\text { (max. 113) }\end{array}$ & $\begin{array}{c}\text { Entire } \\
\text { corpus - } \\
\text { Total } \\
\text { correct } \\
\text { answers } \\
(\%)\end{array}$ & $\begin{array}{c}\text { Compa- } \\
\text { red with } \\
\text { the } \\
\text { bench- } \\
\text { mark } \\
81,56 \%\end{array}$ \\
\hline $\begin{array}{l}\text { D1 (Q14) } \\
\text { Interest in the } \\
\text { topic: } \\
\text { interested }\end{array}$ & 74 & 74 & 12 & 92.31 & 86 & $\mathbf{7 6 . 1 1}$ & -5.54 \\
\hline $\begin{array}{l}\text { D2 (Q9) No. } \\
\text { of references }\end{array}$ & 74 & 74 & 10 & 76.92 & 84 & $\mathbf{7 4 . 3 4}$ & -7.22 \\
\hline $\begin{array}{l}\text { D3 (Q11) } \\
\text { Assumed } \\
\text { author }\end{array}$ & 62 & 62 & 11 & 84.62 & 73 & $\mathbf{6 4 . 6 0}$ & -16.96 \\
\hline $\begin{array}{l}\text { D4 (Q15) } \\
\text { Genre }\end{array}$ & 83 & 83 & 10 & 76.92 & 97 & $\mathbf{8 5 . 8 4}$ & +4.28 \\
\hline $\begin{array}{l}\text { D5 (Q12) The } \\
\text { importance of } \\
\text { the text }\end{array}$ & 15 & 15 & 3 & 23.07 & 18 & $\mathbf{1 5 . 9 3}$ & -65.63 \\
\hline
\end{tabular}

Source: J. Javorčíková

\footnotetext{
${ }^{8}$ This course is one of the most important compulsory course all undergraduates are obliged to take as a starting point to their univeristy studies at the Department of English and American Studies at Matej Bel University.
} 
Entire sample unit: In D1 (Q14), we draw a correlation between interest and motivation, as the topic is directly connected to respondents' future professions. Table 3 shows that in the sample unit as a whole (113 respondents), 86 respondents $(76.11 \%)$ were motivated to read a text related to their field of studies and future profession and found it "important" for themselves and their lives. However, almost a quarter of the sample unit $(23.89 \%)$ found the topic uninteresting and unimportant.

In order to identify respondents' ability to read the text critically, we were also interested in their general ability to understand how an academic text works. All the respondents had already taken the course Introduction to Linguistics, so they were acquainted with basic styles of writing and their attributes. Moreover, they had been exposed to a variety academic texts during the first term of their initial academic year. Thus, they were expected to identify basic academic text attributes, such as academic vocabulary, precise facts and figures, referencing system, complex grammar structures and cautious/tentative language (Mistrík 1997; Gura 2005). In the text, two surveys referred to were explicitly mentioned in line 32 (Surveys like these...) and summatively in line 33 (the two surveys...). In D2 (Q9), 74.34\% of the entire corpus were able to correctly identify the number of sources; however, 29 students $(25.66 \%)$ failed to do so in spite of numerous references.

Critical thinking also requires the ability to gather (deduce, anticipate, decode) a great deal of meta-information about the text and its discourse (Hanesová 2014; Piršl, Popovska and Stojković 2017), including identification of the assumed author or authors (if not stated) and his or her intentions (e.g. to inform, persuade, compare, synthetize, etc.) reflected in the genre of the text. In D3 (Q11), 73 students $(64.60 \%)$ correctly identified the assumed author. In D4 (Q15), 97 students $(85.83 \%)$ could identify the genre of a research article.

D 5 (Q12) was a synthetic type of question. Respondents were to critically evaluate the importance of the text for themselves and their community. Students were given the options of adding their own comments to the pre-selected options, selecting multiple options or none, if they felt that the options did not reflect the true value of the text. Quite surprisingly, only one student indicated more than one option and no student commented on the answers provided. That could indicate that the respondents submitted to the authority of the test; they did not dare to question the options even when encouraged to. In D5 (Q12), as few as 18 students (15.93\%) could grasp the importance of the text.

With regards to the null and alternative hypotheses, the benchmark for "necessary critical thinking skills" was established as $81.56 \%$ correct answers. Table 3 shows that the entire corpus only exceeded $81.56 \%$ correct answers in D4-Identification of the genre $(85.84 \%)$. In all the other questions, the ratio of correct answers was below 81.56\%. In D5-Importance of the text for the individual, the ratio of correct answers was only $15.93 \%$.

Slovak respondents: The Slovak sample unit consisted of 100 respondents. $74 \%$ Slovak students were motivated enough to read the article. $74 \%$ identified the correct number of references, $62 \%$ the assumed author and as many as $83 \%$ the correct genre of the article. However, only $15 \%$ could grasp the importance of the text for themselves and their community. With regards to the benchmark of $81.56 \%$ correct answers, the Slovak corpus achieved results similar to the entire corpus; only D4-Identification of the genre exceeded the benchmark (83\%).

International respondents: Comparatively, international students were more motivated than Slovak students (by $18.31 \%$ ), better prepared to identify the assumed author (by 22.62\%) and number of references (by 2.92\%), and better prepared to verbalize the overall importance of the text for themselves and their community (by 
$8.07 \%)$. The international respondents were only outscored by the Slovak respondents in genre identification (by $7.92 \%$ ). In terms of the pre-set benchmark of $81.56 \%$, the international respondents exceeded it in items D1 and D3.

The aim of the presented research was to determine whether Slovak university undergraduate students who continue in their studies $(81.56 \%)$ have a good command of critical thinking skills when reading a new academic text. The research verified hypothesis $\mathrm{H}_{0}$ in four out of five tested items (D1, D2, D3 and D5):

$\mathrm{H}_{0}: 81.56 \%$ of first-year undergraduates do not have the necessary critical thinking skills for academic reading.

The alternative hypothesis was confirmed in only one item (D4):

$\mathrm{H}_{1}: 81.56 \%$ of first-year undergraduates have the necessary critical thinking skills for academic reading.

If we compare the national and international corpus, the international respondents exceeded the correct answer ratio in two items (D1, D3).

\section{RESULTS}

The research showed that:

- $23.89 \%$ of the entire corpus of first-year undergraduates lacked adequate interest in the topic of their future career $(-5.54 \%$ in comparison with the benchmark $81.56 \%)$

- $25.66 \%$ could not identify the accurate number of references $(-7.22 \% / 81.56 \%)$

- $35.40 \%$ could not identify the assumed author $(-16.96 \% / 81.56 \%)$

- an alarming $84.07 \%$ could not grasp the importance of the text for themselves and their community $(-65.63 \% / 81.56 \%)$

A positive result was that the respondents, having taken the course in Introduction to Linguistics and been in contact with academic texts, could identify the genre of the text above the correct answer ratio (+ 4. 28).

Potential reasons for this may be manifold; underachieving respondents need more guidance (perhaps a course in fundamental academic skills) in academic reading, evaluation and critical thinking. They also need a course in academic English in order to distinguish between terms such as survey, literacy, research, etc.

On the other hand, as Larson pointed out in Critical Thinking in Slovakia after Socialism (2013), the reasons may also lie more deeply in the history of the Slovak educational system, rooted in the traditional pragmatic approach to education. If we want to follow innovative trends in specialized didactics (Židová 2018), such as a student-centred approach and an adequate educational policy (Rošteková 2019; Kolečáni-Lenčová, 2020), and foster students' critical thinking, we need to focus on the essential characteristics and conditions that will allow for their implementation. Lipman summarises the importance of the fusion of teaching and leading out critical thinking: "Our contemporary conception of education as inquiry combines two aims - the transmission of knowledge and the cultivation of wisdom. [...] The line of inquiry we are taking shows wisdom to be the characteristic outcome of good judgement and good judgement to be the characteristic of critical thinking" (Lipman 1988, 38).

As indicated by Browne and Keely as early as $1981(1981,8)$ and proved by the recent development in research of reading (Alderson 2005, Gavora 2012), reading 
comprehension and critical and independent thinking have become more integrated over the years: “...independent thinkers (S-1 strategy) strive to incorporate all known relevant knowledge (and the knowledge gathered via reading) and insight into their thought and behaviour. They strive to determine for themselves when information is relevant, when to apply a concept, or when to make use of a skill. They are self-monitoring: they catch their own mistakes; they do not need to be told what to do every step of the way" (Paul 1995). Moreover, they integrate their cultural awareness into the overall evaluation of the text and its meaning (Höhn, 2020) for themselves and their well-being. Thus the critical thinking framework which is based on the best theories and practices in this field and is suitable for any discipline (including reading comprehension training) and remains crucial to all students studying in academic courses, and to university teachers as well (Badinská and Bathgate 2016).

\section{CONCLUSION}

The present study analysed the reading comprehension and critical thinking skills of 113 first-year university undergraduates in humanities at Matej Bel University, Slovakia. Quite alarmingly, the entire sample unit reached the retention benchmark of $81,56 \%$ in only one analysed item (D4-genre; 85.84\%). They also seriously lacked the abilities needed to grasp the importance of the text (15.93\% correct answers).

This research draws attention to a serious academic inconsistency $-81.56 \%$ students who continue in their studies (i.e. professional readers) lack the academic skills to read professionally. Moreover, only $76.11 \%$ students are motivated to read about topics related to their studies and future professions, and even those lack abilities for effective reading: $35.40 \%$ were not able to identify the assumed author of the text, $14.16 \%$ could not identify the number of references and an alarming $84.07 \%$ could not identify the importance of the text, either by selection from the pre-set options or by using their own wording. As no similar research has been conducted in Slovakia, no comparable data are available; another setback of the research might lie in the limited number of questions testing critical reading sub-skills; in subsequent research, we also intend to verify quantitative results by interviews with respondents.

Our analysis of the sample unit's reading results suggests that Slovak students need more instruction and guidance in order to read effectively and think critically. A placement test of their initial skills upon entering academia as well as a customised course reflecting their real skills and potential to improve would help them to become more independent readers and to read more effectively and critically, which will eventually translate into their academic and professional success.

This article is the outcome of the project VEGA 1/0437/19 (Cultural and Educational Agency of the Ministry of Education, Science, Research and Sport or the Slovak Republic) entitled The importance of internationalization of university education for the construction of the EU identity and for the increase of competition in the European space.

This article is the outcome of the project VEGA 1/0118/20 (Cultural and Educational Agency of the Ministry of Education, Science, Research and Sport or the Slovak Republic) entitled Dyslexia as a linguistic-cognitive disorder and its symptoms in developing reading literacy in mother and foreign (English) Tongue. 


\section{REFERENCES}

Alderson, Charles J. 2005. Assessing Reading. Cambridge: Cambridge University Press.

Badinská, Mária, and Frances M. Bathgate. 2016. "The Application of the Paulian Framework of Critical Thinking to Human Rights Education at the Tertiary Level." In Human Forum, edited by Jarmila Androvičová, 89-101. Banská Bystrica: Belianum.

Cameron, Lynne. 2001. Teaching Languages to Young Learners. Cambridge: Cambridge University Press.

Cottrell, Stella. 2005. Critical Thinking Skills. Developing Effective Analysis and Argument. New York: Palgrave Macmillan.

Browne, Neill M., and Stuart M. Keeley. 1981. Asking the Right Questions - A Guide to Critical Thinking. Englewood Cliffs: Prentice-Hall.

Duron, Robert, W., Barbara Limbach, and Walter Waugh. 2006. "Critical Thinking Framework for Any Discipline." International Journal of Teaching and Learning in Higher Education 17 (2): 160-166.

Elder, Linda, and Richard Paul. 1996. The Analysis and Assessment of Thinking. Tomales: Foundation For Critical Thinking.

Elder, Linda, and Richard Paul. 1997. "Critical Thinking: Crucial Distinctions for Questioning.” Journal of Developmental Education 21, no. 2 (Winter): 34-35.

Ennis, Robert, H. 2011. "The nature of Critical Thinking: An Outline of Critical Thinking Dispositions and Abilities." The Sixth International Conference on Thinking at MIT, Cambridge, MA, July, 1994. Last modified May 1, 2011.

http://faculty.education.Illinois.edu/rhennis/documents/TheNatureofCriticalThinking_517 11_000.pdf

Gavora, Peter, ed. 2012. Ako rozvijat' porozumenie textu u žiaka. Nitra: Enigma.

Grabe, William, and Fredericka. L. Stoller. 2011. Teaching and Researching Reading. Harlow: Pearson Education.

Gura, Radovan. 2005. "Práca s odborným písaným textom - Compte Rendu" In Sborník př́spěvků z konference Profilingua, edited by Zlata Hokrová, 114-118. Plzeň: Západočeská univerzita.

Hanesová, Dana. 2014. From Learning Facts to Learning to Think. Banská Bystrica: PF.

Hankerová, Kristína. 2019. Dyslexia a rozvíjanie čitatel'skej gramotnosti v cudzích jazykoch. In Aplikované jazyky $v$ univerzitnom kontexte VI., edited by Žaneta Balážová, 50-59. Zvolen: TU.

Höhn, Eva. 2020. "Kultúrna identita” In Mestá a ich príbehy-európska učebnica o kultúrnych tradíciách, edited by Eva Höhn, 21-28. Banská Bystrica: DALI BB.

Javorčíková, Jana, and Stanislav Kováč. 2018. "Motivation to read: facts and myths.” In Radomskie studia filologiczne 7 (1): 27-36.

Kolečáni-Lenčová, Ivica. 2020. Linguistic Landscape and Reading Comprehension in foreign Language Teaching. AD ALTA : Journal of Interdisciplinary Research 10 (1): 160-164.

Koper, Ján, and Branislav Kováčik et al. 2019. Postdemokracia ako proces hl'adania novej kvality demokracie. Praha: Naše vojsko.

Larson, Jonathan L. 2013. Critical Thinking in Slovakia after Socialism. Rochester: University of Rochester Press.

Lipman, Mathew. 1988. "Critical Thinking - What Can It Be?" In Educational Leadership 46, no. 1 (September): 38-43. 
Lojová, Gabriela, and Zuzana Straková. 2012. Teoretické východiská vyučovania angličtiny v primárnom vzdelávaní. Bratislava: Univerzita Komenského.

Mistrík, Jozef. 1997. Štylistika. Bratislava: Slovenské pedagogické nakladatel'stvo.

Oxenden, Clive, and Christianna Latham-Koenig et al. 2001. English File (Upperintermediate). Oxford: Oxford University Press.

Oxford, Rebecca L. 1990. Language Learning Strategies: What every teacher should know. New York: Newsbury House.

Paul, Richard. 1995. Critical Thinking: How to Prepare Students for a Rapidly Changing World. New York: Foundation for Critical Thinking.

Paul, Richard. 2005. Critical Thinking: What? Why? How? January 6, 2021, https://ctwhatwhyhow.weebly.com/richard-paul.html

Paul, Richard, A.J.Å. Binker, Douglas Martin, and Ken Adamson. 1995. Critical Thinking Handbook: High School: (A Guide for Redesigning Instructions). Santa Rosa: Foundation for Critical Thinking.

Paul, Richard, and Lynne Elder. 2006. The Thinker's Guide to The Art of Socratic Questioning. Tomales: The Foundation for Critical Thinking.

Piršl, Danica, Solzica Popovska, and Nadezda Stojković. 2017. "Critical Thinking, Strategic Learning and Metacognition in ESP." The Journal for Teaching English for Specific and Academic Purposes 5 (3): 603-613.

PISA (OECD). 2018. "Snapshot of Student Performance." Accessed May 3, 2021. https://www.oecd.org/pisa/PISA-results_ENGLISH.png

Rošteková, Mária. 2019. "In search of adequate educational policy for foreign language teaching in Slovakia.” In XLinguae: European Scientific Language Journal 12, no. 1XL (2019): 66-81.

Scholes, Robert. 1991. Protocols of Reading. New Haven: Yale University Press.

Sartori, Giovanni. 1993. Teória demokracie. Bratislava: Archa.

Skills You Need. 2020. "What is Communication?" Last modified March 1, 2021. https://www.skillsyouneed.com/learn/critical-thinking.html

Straková, Zuzana, and Ivana Cimermanová. 2005. Teaching and learning English language. Prešov: Fakulta humanitných a prírodných vied Prešovskej univerzity.

Šipošová, Martina. 2017. Konštruktivistické aspekty v procese rozvíjania čítania s porozumením ako prostriedok zdokonal'ovania odbornej jazykovej spôsobilosti na ceste ku kompetenciám. In Aplikované jazyky v univerzitnom kontexte IV., edited by Žaneta Balážová, 27-42. Zvolen: TU.

Štefániková, Lenka. 2019. Transformácia politických strán z postdemokratickej perspektívy. In Postdemokracia ako proces hl'adania novej kvality demokracie, edited by Ján Koper, 79-96. Praha: Naše Vojsko.

Veverková, Darina. 2020. Rozvíjanie cudzojazyčnej čitatel’skej kompetencie pri práci s odborným textom. Zvolen: TU.

Zápotočná, Ol'ga. 2001. Rozvoj počiatočnej literárnej gramotnosti. In Predškolská a elementárna pedagogika, edited by Branislav Pupala, 271-306. Praha: Portál.

Židová, Diana. 2018. Reading between the lines and intercultural communication in contemporary British fiction. In Inovatívne trendy $v$ odborových didaktikách $v$ kontexte požiadaviek praxe, edited by Jana Duchovičová, 313-319. Nitra: PF UKF. 